\title{
THE ROLE OF ALPHA HAEMOLYSIN IN THE VIRULENCE OF ESCHERICHIA COLI FOR MICE
}

\author{
Margaret A. LingGOOD* AND P. L. INGRAM \\ The Royal Veterinary College, Hawkshead House, North Mimms, Hatfield, Herts
}

Summary. Transfer of an Hly plasmid determining production of $\alpha$ haemolysin to a non-haemolytic strain of Escherichia coli increased the virulence of the strain for mice. Injections of non-toxic amounts of $\alpha$ haemolysin, phenylhydrazine, haemoglobin, iron or manganese salts simulated the effect of the Hly plasmid by stimulating bacterial growth. Active or passive immunisation against $\alpha$ haemolysin protected mice on challenge with haemolytic $E$. coli by inhibiting in-vivo proliferation of the strain. Protection was eliminated by administration of iron salts at the time of challenge. The Hly plasmid probably acts as a virulence factor by enabling haemolytic strains of $E$. coli to obtain iron for growth from the lysed erythrocytes of infected animals.

\section{INTRODUCTION}

In the blood of most animals iron, which is essential for bacterial growth, exists in an unavailable form, e.g., bound to the serum transferrin or as part of the haemoglobin of erythrocytes. Various invasive bacteria obtain iron from the host by specific mechanisms such as high-affinity chelators which compete with transferrin for iron, one such example being the chelator in the cell walls of some invasive strains of Escherichia coli that is coded for by the ColV plasmid (Williams, 1979).

The virulence of $E$. coli for mice is increased by haemoglobin or iron salts (Bornside, Bouis and Cohn, 1968) or by haemolysis of the blood of infected animals (Kaye and Hook, 1963). Thus, it is of interest that many strains of $E$. coli pathogenic for pigs produce an extracellular plasmid-determined haemolysin and the purpose of the present paper is to establish whether $\alpha$ haemolysin acts as a virulence factor by increasing the amount of iron available for the growth of invasive strains of $E$. coli in host animals.

\section{MATERIALS AND METHODS}

Bacteria. Two naturally occurring haemolytic strains of E. coli were used: P5 (O141:K85, $\mathrm{K} 88 \mathrm{ab}$ ), an enterotoxigenic strain isolated from a scouring pig, and PM167, a non-enterotoxigenic strain isolated from the faeces of a healthy pig. The non-haemolytic strain $\mathrm{P} 5 \mathrm{Hly}^{-}$was a variant of strain P5 that had lost its Hly, K88 and Col plasmids naturally. The haemolytic variant $\mathrm{P} 5 \mathrm{Hly}^{+}$, used to challenge mice, was prepared by the transfer to strain $\mathrm{P} 5 \mathrm{Hly}^{-}$of $\mathrm{Hly}$

Received 4 Mar. 1981; revised version accepted 10 Jul. 1981

* Present address: Unilever Research, Colworth House, Sharnbrook, Bedford MK44 1LQ. 
plasmid trom strain P316. Strains 711(P5) $\mathrm{Hly}^{+}, \mathrm{F} 11(\mathrm{P} 5) \mathrm{Hly}^{+}$and 711(PM167) $\mathrm{Hly}^{+}$, from which haemolysin was prepared, were constructed by the transfer of Hly plasmids from $\mathrm{P} 5$ or

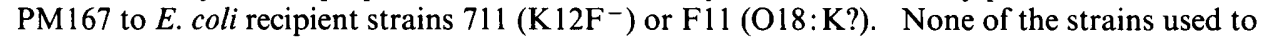
infect mice or to prepare $\alpha$ haemolysin produced a colicine active against $E$. coli strain K12.

Preparation of $\alpha$ haemolysin. The haemolytic strains 711(P5), F11(P5) and 711(PM167) were grown in static alkaline extract broth (Smith, 1963) at $37^{\circ} \mathrm{C}$ for $2.5 \mathrm{~h}$. The extracellular haemolysin precipitated from the culture supernate with $22 \%(\mathrm{w} / \mathrm{v})$ ammonium sulphate was redissolved in isotonic saline to half its original volume. These preparations are referred to as HAEM preparations. Control NH preparations were made from the non-haemolytic strain 711 $\mathrm{Hly}^{-}$cultured and treated similarly.

The preparation in rabbits of antiserum to F11(P5) HAEM, and the determination of haemolysin and anti-haemolysin titres were performed as described by Smith (1963).

Challenge of mice. Strains of E. coli were grown in static nutrient broth for $18 \mathrm{~h}$, diluted in isotonic saline and $0.5-\mathrm{ml}$ volumes injected intraperitoneally into mice, which were observed for 2 days after challenge and the time of death noted. The LD50 values of the haemolytic and non-haemolytic forms of strain P5 were initially determined by the method of Reed and Muench (1938). In later experiments, mice were challenged with c. $5 \times 10^{7}$ non-haemolytic bacteria (about half the LD50) or 1-2 $\times 10^{7}$ haemolytic bacteria, an infecting dose slightly greater than the LD50. The HAEM or NH preparations were injected into the tail vein immediately before or after challenge. Haemoglobin prepared from lysed erythrocytes or salt solutions $(500 \mu \mathrm{g} / \mathrm{ml}$ in isotonic saline) were injected intraperitoneally in volumes of, respectively, 0.5 and $0.4 \mathrm{ml}, 10 \mathrm{~min}$ before challenge. Phenylhydrazine hydrochloride solution $(25 \mathrm{mg} / \mathrm{ml}$ in isotonic saline) was injected subcutaneously in $0 \cdot 1-\mathrm{ml}$ amounts $90-120 \mathrm{~min}$ before, or $45 \mathrm{~min}$ after, challenge. Necropsy was performed on mice immediately after they had died or had been killed. Each liver was ground up, suspended in $10 \mathrm{ml}$ of sterile saline and the number of viable bacteria (colony-forming units) recovered from the liver estimated by a method based on that described by Miles, Misra and Irwin (1938).

Immunisation. Mice were immunised: actively by intravenous inoculations of HAEM or NH preparations $(0 \cdot 2-0 \cdot 3 \mathrm{ml})$ on days 1,5 and 10 ; or passively by intraperitoneal inoculation of antihaemolytic or normal rabbit serum $(0.7 \mathrm{ml})$ previously heated in a waterbath at $56^{\circ} \mathrm{C}$ for $1 \mathrm{~h}$.

\section{RESULTS}

\section{The influence of the Hly plasmid on the infectivity of E. coli for mice}

The virulence of strain P5 $\mathrm{Hly}^{-}$was increased approximately tenfold by acquisition of the Hly plasmid. As judged by the numbers of viable E. coli recovered from the liver of infected mice, strain $\mathrm{P} 5 \mathrm{Hly}^{-}$proliferated less well in vivo than strain $\mathrm{P} 5(\mathrm{P} 316) \mathrm{Hly}^{+}$. However, when mice were infected with a mixture of the two types of the strain, the non-haemolytic form proliferated as well as the haemolytic form (table I).

\section{Toxicity of haemolysin for mice}

The results of giving mice HAEM, heat-treated HAEM $\left(56^{\circ} \mathrm{C}\right.$ for $\left.10 \mathrm{~min}\right)$ and NH preparations intravenously are summarised in table II. The variation in the toxicity of the different HAEM preparations was not related to their $\alpha$-haemolysin titre. For example, HAEM preparation E was more toxic than other HAEM preparations and 711(PM167) HAEM preparation 2 retained slight toxicity after heat treatment had destroyed its haemolytic activity. HAEM and NH preparations contained other constituents precipitated from the bacterial supernates by $22 \%$ ammonium sulphate and trace amounts of 
TABLE I

The proliferation in mice of haemolytic and non-haemolytic variants of E. coli P5; typical results, from one animal

\begin{tabular}{|c|c|c|c|c|}
\hline \multirow{3}{*}{$\begin{array}{l}\text { Time (hours) } \\
\text { after challenge } \\
\text { that mice were } \\
\text { killed }\end{array}$} & \multicolumn{4}{|c|}{ Number of organisms $\left(\log _{10}\right)$} \\
\hline & \multicolumn{2}{|c|}{$\begin{array}{l}\text { in inoculum } \\
\text { of strain }\end{array}$} & \multicolumn{2}{|c|}{$\begin{array}{l}\text { recovered per } \\
\text { mouse liver } \\
\text { of strain }\end{array}$} \\
\hline & P5 $\mathrm{Hly}^{+}$ & $\mathrm{P} \mathrm{Hly}^{-}$ & P5 $\mathrm{Hly}^{+}$ & P5 $\mathrm{Hly}^{-}$ \\
\hline $\begin{array}{l}4^{*} \\
6 \cdot 5^{*} \\
8^{*} \\
4 \dagger \\
6 \cdot 5 \dagger \\
3 \dagger \\
4^{\dagger} \\
6 \cdot 5 \dagger \\
8^{\dagger}\end{array}$ & $\begin{array}{l}0 \\
0 \\
0 \\
7 \cdot 60 \\
7 \cdot 48 \\
7 \cdot 26 \\
7 \cdot 30 \\
7 \cdot 18 \\
7 \cdot 13\end{array}$ & $\begin{array}{l}7 \cdot 34 \\
7 \cdot 08 \\
7 \cdot 34 \\
0 \\
0 \\
7 \cdot 28 \\
7 \cdot 04 \\
6 \cdot 78 \\
7 \cdot 13\end{array}$ & $\begin{array}{l}0 \\
0 \\
0 \\
7 \cdot 26 \\
7 \cdot 28 \\
6 \cdot 78 \\
7 \cdot 38 \\
7 \cdot 15 \\
6 \cdot 78\end{array}$ & $\begin{array}{l}4 \cdot 90 \\
5 \cdot 52 \\
4 \cdot 70 \\
0 \\
0 \\
6 \cdot 95 \\
7 \cdot 20 \\
7 \cdot 04 \\
6.95\end{array}$ \\
\hline
\end{tabular}

endotoxin were usually precipitated by $25 \%$ ammonium sulphate. Thus, HAEM preparation E may have contained more endotoxin than other preparations.

Factors influencing the virulence of non-haemolytic E. coli

The results of experiments in which HAEM or NH preparations were given intravenously to mice shortly before or after the non-haemolytic infecting strain P5 $\mathrm{Hly}^{-}$are shown in table III. Mice in which HAEM preparation 711(P5) had been injected were more susceptible to infection than mice given

TABLE II

Effect of preparations from haemolytic and non-haemolytic strains of E. coli given intravenously* to mice

\begin{tabular}{l|cc}
\hline $\begin{array}{c}\text { Preparation/ } \\
\text { from strain }\end{array}$ & $\begin{array}{c}\alpha \text {-Haemolysin } \\
\text { titre }\end{array}$ & $\begin{array}{c}\text { Number of mice dead/total } \\
\text { number challenged }\end{array}$ \\
\hline HAEM/711(P5)Hly ${ }^{+}:$ & & \\
A & 120 & $3 / 13$ \\
B & 160 & $1 / 57$ \\
D & 160 & $0 / 14$ \\
E & 160 & $4 / 7$ \\
H & 120 & $1 / 21$ \\
H, heated $\dagger$ & $<5$ & $0 / 10$ \\
HAEM/711(PM167)Hly ${ }^{+}:$ & 160 & $2 / 21$ \\
I heated $\dagger$ & $<5$ & $0 / 7$ \\
2, head & 160 & $2 / 7$ \\
2, heated $\dagger$ & $<5$ & $1 / 7$ \\
NH/711 Hly & & \\
1 & $<5$ & $0 / 95$ \\
\hline
\end{tabular}

$\mathrm{HAEM}=$ preparation from haemolytic and $\mathrm{NH}=$ from non-haemolytic strain

$* 0.15-0.5 \mathrm{ml}$

$+56 \mathrm{C}$ for $10 \mathrm{~min}$. 
TABLE III

Effect of HAEM or NH preparations on mice infected with non-haemolytic E. coli strain P5 Hly ${ }^{-}$

\begin{tabular}{|c|c|c|c|}
\hline $\begin{array}{l}\text { Preparation/ } \\
\text { from strain }\end{array}$ & $\begin{array}{l}\text { Administered } \\
\text { before or after } \\
\text { challenge }\end{array}$ & $\begin{array}{l}\text { Number of mice } \\
\text { dead/number } \\
\text { infected }\end{array}$ & $\begin{array}{c}\text { Mean } \\
\text { number of } \\
\left.\text { organisms (log } \log _{10}\right) \\
\text { per mouse liver* }\end{array}$ \\
\hline \multicolumn{4}{|l|}{ HAEM/711(P5)Hly ${ }^{+}$: } \\
\hline & After & $11 / 20$ & $6 \cdot 77$ \\
\hline Heated $\dagger$ & Before & $0 / 6$ & $3 \cdot 38$ \\
\hline \multirow{2}{*}{$\begin{array}{l}\mathrm{NH} / 711 \mathrm{Hly}^{-} \text {: } \\
\text { Untreated }\end{array}$} & After & $0 / 3$ & $3 \cdot 48$ \\
\hline & $\begin{array}{l}\text { Before } \\
\text { After }\end{array}$ & $\begin{array}{l}0 / 16 \\
0 / 16\end{array}$ & $\begin{array}{l}3 \cdot 26 \\
5 \cdot 42\end{array}$ \\
\hline
\end{tabular}

Abbreviations as in table II.

* Viable counts made $19-24 \mathrm{~h}$ after challenge with $\mathrm{c} 5 \times 10^{7}$ E. coli strain P5 $\mathrm{Hly}^{-}$. $+56^{\circ} \mathrm{C}$ for $10 \mathrm{~min}$.

$\mathrm{NH}$ or heat-treated HAEM. Death usually occurred about $24 \mathrm{~h}$ after challenge. Transient haemoglobinuria was observed about $2 \mathrm{~h}$ after the mice had received HAEM and the number of non-haemolytic $E$. coli recovered from the liver of these mice was considerably higher than that recovered from mice given $\mathrm{NH}$ or heat-treated HAEM but otherwise treated similarly.

Enhancement of the virulence of strain P5 $\mathrm{Hly}^{-}$was also achieved by subcutaneous injection of phenylhydrazine hydrochloride (table IV). The number of bacteria recovered $17 \mathrm{~h}$ after challenge from the liver of the phenylhydrazine-treated mice was higher than that of control mice. Subcutaneous injection of phenylhydrazine solution caused haemolytic anaemia but not death in uninfected mice. Whereas the haematocrit of uninfected mice was $45-50 \%$, that of mice given phenylhydrazine fell to $31-35 \%$ in about $4 \mathrm{~h}$, remained low for 3 days and returned to normal after 1 week. The haemoglobinuria noted in mice given a HAEM preparation was absent from the phenylhydrazine-treated mice, the urine of which, however, became slightly brown as the phenylhydrazine treatment resulted in the reduction and denaturation of oxyhaemoglobin to a ferrihaemochrome.

The intraperitoneal injection of ferrous sulphate, ferric ammonium citrate, manganese chloride or haemoglobin just before challenge similarly increased the virulence of strain P5 $\mathrm{Hly}^{-}$and mice usually died within 18-24 h. As judged by the number of bacteria recovered from the liver, strain $\mathrm{P} 5 \mathrm{Hly}^{-}$had

TABLE IV

Effect of phenylhydrazine on mice infected with non-haemolytic E. coli strain P5 Hly-

\begin{tabular}{l|cc}
\hline $\begin{array}{c}\text { Treatment of } \\
\text { mice with }\end{array}$ & $\begin{array}{c}\text { Number of mice } \\
\text { dead/number } \\
\text { infected }\end{array}$ & $\begin{array}{c}\text { Number of organisms } \\
\left(\log _{10}\right) \text { per mouse } \\
\text { liver* }\end{array}$ \\
\hline $\begin{array}{l}\text { Saline (controls) } \\
\text { Phenylhydrazine } \mathrm{HCl} \dagger\end{array}$ & $0 / 24$ & $4 \cdot 53$ \\
\hline
\end{tabular}

* Mean of viable counts made $17 \mathrm{~h}$ after challenge with $c .5 \times 10^{7}$ E. coli strain P5 Hly-.

$\dagger$ Phenylhydrazine $\mathrm{HCl}(2.5 \mathrm{mg})$ was injected subcutaneously $90-120 \mathrm{~min}$ before or $45 \mathrm{~min}$ after challenge. 
TABLE V

Effect of different cations and haemoglobin on mice infected with non-haemolytic E. coli strain P5 $\mathrm{Hly}^{-}$

\begin{tabular}{l|cc}
\hline \multicolumn{1}{c|}{$\begin{array}{c}\text { Treatment* of } \\
\text { mice with }\end{array}$} & $\begin{array}{c}\text { Number of mice } \\
\text { dead/ } \\
\text { number infected }\end{array}$ & $\begin{array}{c}\text { Number of organisms } \\
\left(\log _{10}\right) \text { per mouse } \\
\text { liver } \dagger\end{array}$ \\
\hline Saline & $1 / 30$ & $4 \cdot 28$ \\
Calcium chloride & $0 / 10$ & $4 \cdot 78$ \\
Magnesium sulphate & $0 / 12$ & $4 \cdot 42$ \\
Manganese chloride & $9 / 12$ & $7 \cdot 70$ \\
Ferrous sulphate & $12 / 12$ & $8 \cdot 04$ \\
Ferric ammonium citrate & $5 / 7$ & $8 \cdot 08$ \\
Haemoglobin & $10 / 10$ & $9 \cdot 00$ \\
\hline
\end{tabular}

* Salt solutions $(200 \mu \mathrm{g})$ or haemoglobin were injected intraperitoneally before $(10 \mathrm{~min})$ challenge with $c$. $5 \times 10^{7}$ E. coli strain P5 $\mathrm{Hly}^{-}$.

$\dagger$ Mean of viable counts made $18-24 \mathrm{~h}$ after challenge.

proliferated in mice given iron salts, manganese sulphate or haemoglobin but not in those mice given calcium chloride, magnesium sulphate or isotonic saline (table V). Intraperitoneal injection of the various salt solutions had no adverse effects in uninfected mice.

\section{Protection by antihaemolysins against challenge by haemolytic E. coli}

One injection of HAEM preparation did not confer immunity to challenge 12 days later by strain P5(316) $\mathrm{Hly}^{+}$. On the other hand, three injections at 5-day intervals of either of the HAEM preparations 711(P5) or 711(PM167) protected mice against challenge by strain $\mathrm{P} 5(\mathrm{P} 316) \mathrm{Hly}+5$ days after the third injection (table VI). Similar treatment with either $\mathrm{NH}$ preparation or heat-treated HAEM preparations did not protect the mice, which usually developed haemoglobinuria 4 or $5 \mathrm{~h}$ after challenge and died a further $3 \mathrm{~h}$ later.

TABLE VI

Survival of actively immunised mice after intraperitoneal challenge with haemolytic E. coli strain P5 (P316) Hly ${ }^{+}$

\begin{tabular}{|c|c|c|c|}
\hline $\begin{array}{l}\text { Immunising } \\
\text { preparation }\end{array}$ & $\underset{\text { titre }}{\alpha \text {-Haemolysin }}$ & $\begin{array}{l}\text { Number of mice } \\
\text { dead/number } \\
\text { infected }\end{array}$ & $\begin{array}{c}\text { Number of } \\
\text { organisms }\left(\log _{10}\right) \\
\text { per mouse liver* }\end{array}$ \\
\hline $\begin{array}{l}\text { HAEM/711(P5)Hly }{ }^{+}: \\
\text {unheated } \\
\text { unheated }+\mathrm{Fe}^{\dagger} \\
\text { heated }+ \\
\text { HAEM/711(PM167)Hly }{ }^{+} \text {: } \\
\text { unheated } \\
\text { heated }+ \\
\text { NH/711 Hly } \\
\text { unheated }\end{array}$ & $\begin{array}{c}120-160 \\
120-160 \\
<5 \\
120-160 \\
<5 \\
<5\end{array}$ & $\begin{array}{l}0 / 24 \\
6 / 6 \\
8 / 10\end{array}$ & $\begin{array}{l}4 \cdot 62 \\
8 \cdot 32 \\
7 \cdot 11\end{array}$ \\
\hline
\end{tabular}

Abbreviations as in table II.

* Mean of viable counts made 5-9 h after challenge with $c .1 \times 10^{7}$ E. coli strain P5 Hly ${ }^{+}$.

+ Ferric ammonium citrate $(250 \mu \mathrm{g})$ administered at time of challenge.

$\ddagger 56 \mathrm{C}$ for $10 \mathrm{~min}$. 
TABLE VII

Survival of passively immunised mice after intraperitoneal challenge with haemolytic E. coli strain P5 (316) Hly ${ }^{+}$

\begin{tabular}{lc|cc}
\hline \multicolumn{1}{c|}{$\begin{array}{c}\text { Serum* } \\
\text { administered }\end{array}$} & $\begin{array}{c}\text { Time (hours) } \\
\text { serum given } \\
\text { before challenge }\end{array}$ & $\begin{array}{c}\text { Number of mice } \\
\text { dead/total number } \\
\text { infected }\end{array}$ & $\begin{array}{c}\text { Mean logio number } \\
\text { of organisms per liver } \\
\text { at 7 (and 24) } \mathrm{h} \text { after } \\
\text { challenget }\end{array}$ \\
\hline Anti-HAEM, F1l(P5)Hly ${ }^{+}$ & 24 & $0 / 13$ & $5 \cdot 08(2 \cdot 90)$ \\
Normal rabbit serum & 48 & $0 / 14$ & $\mathrm{ND}$ \\
(controls) & 24 & $12 / 13$ & $7 \cdot 34(8 \cdot 00)$ \\
\hline
\end{tabular}

Abbreviations as in table II.

* $0.7 \mathrm{ml}$ injected intraperitoneally before challenge.

+ Challenge with $c .4 \times 10^{7}$ E. coli strain P5 Hly ${ }^{+}$.

$\mathrm{ND}=$ not determined.

In the protected mice, which did not develop haemoglobinuria and remained healthy, the haemolytic bacteria proliferated less well than in control mice (table VI). Protection was reversed by the intraperitoneal administration of iron at the time of challenge and mice so treated succumbed to infection without developing haemoglobinuria.

Mice were protected by rabbit antihaemolytic serum given 1 or 2 days before challenge by haemolytic strain P5. They did not develop haemoglobinuria and the count of haemolytic $E$. coli remained low compared with that of control mice (table VII). The symptoms in the control mice were similar to those of the unprotected mice described above. The $\alpha$-antihaemolysin titre of the rabbit antiserum that conferred protection was 240 and that of the normal rabbit serum $7 \cdot 5$.

Antihaemolysins had no direct inhibitory effect on the growth of haemolytic $E$. coli in vitro. When mixtures of the haemolytic and nonhaemolytic forms of strain P5 were grown in nutrient broth or in unheated or heated antiserum, the latter with and without added complement, there were no significant differences in the relative numbers of the two forms of the strain after growth for $3 \mathrm{~h}$.

\section{DISCUSSION}

The results of the present study suggest that the presence of the Hly plasmid enhanced virulence by enabling haemolytic strains of $E$. coli to obtain the iron necessary for growth by lysis of erythrocytes in the infected mice. Rapid bacterial proliferation then occurred leading to the deaths of the animals. The role of $\alpha$ haemolysin in stimulating bacterial growth was shown by our finding that avirulent, non-haemolytic strains of $E$. coli proliferated and killed mice when injected along with non-toxic amounts of partially purified haemolysin, and that the presence of $\alpha$ antihaemolysins resulting from active or passive immunisation protected against infection by inhibiting the proliferation of normally virulent haemolytic strains. Protection was provided regardless of whether the haemolysin used as a vaccine was derived from a porcine 
enteropathogenic or a non-pathogenic strain of $E$. coli. If a substance other than $\alpha$ haemolysin stimulated the formation of the protective antibodies, the determinant of that substance must have been transferred along with Hly plasmids to strain 711 from each of these strains.

Stimulation of bacterial growth was also achieved in mice in which the availability of iron was increased by intravascular haemolysis induced by phenylhydrazine hydrochloride or by injection of haemoglobin, or iron or manganese salts. The virulence-enhancing effect of manganese has also been observed in Listeria monocytogenes infections in mice (Sword, 1966) and was considered to result from the displacement of bound iron from transferrin by manganese cations.

Although many strains of $E$. coli that cause enteric disease in pigs are haemolytic (Sojka, 1973), the role of $\alpha$ haemolysin in $E$. coli infections has not been clarified. In enterotoxic colibacillosis, the enteropathogen is normally confined to the alimentary tract (Smith and Jones, 1963), in which $\alpha$ haemolysin is unlikely to be active. It is not surprising, therefore, that loss of the Hly plasmid did not affect the ability of enteropathogenic strains of $E$. coli to cause diarrhoea in pigs (Smith and Linggood, 1971). On the other hand, in bacteraemic conditions the presence of the Hly plasmid might be important. In conditions of normal husbandry, piglets during the first few hours of life receive, from the sow, colostrum rich in antibodies to many $E$. coli antigens including haemolysin (Smith, 1963). Bacteraemic infections caused by E. coli are rare in conventionally reared piglets; colostrum-deprived animals, on the other hand, are susceptible. Lecce and Reep (1962) reported that strains of $E$. coli of serogroup $\mathrm{O} 8$, that are enterotoxigenic and usually associated with enteric infections, were responsible for $67 \%$ of the cases of bacteraemia in piglets but they did not record the haemolytic status of the strains. However, other studies have indicated that strains of serogroup 08 are usually haemolytic (Sojka, 1965) and it is possible that possession of the Hly plasmid enhanced the invasiveness of these strains.

M.A.L. was the recipient of a grant from the Wellcome Trust during this work.

\section{REFERENCES}

Bornside, G. H., Bouis, P. J. AND COHn, I. 1968. Hemoglobin and Escherichia coli, a lethal intraperitoneal combination. J. Bact., 95, 1967.

KAYE, D. AND HOOK, E. W. 1963. The influence of hemolysis or blood loss on susceptibility to infection. J. Immun., 91, 65.

LECCE, J. G. AND REEP, B. R. 1962. Escherichia coli associated with colostrum-free neonatal pigs raised in isolation. J. exp. Med., 115, 491.

Miles, A. A., MisRa, S. S. AND IRwin, J. O. 1938. The estimation of the bactericidal power of the blood. J. Hyg., Camb., 38, 732.

REED, L. J. AND MUENCH, H. 1938. A simple method of estimating 50 percent endpoints. Am. J. Hyg., 27, 493.

Smith, H.W. 1963. The haemolysins of Escherichia coli. J. Path. Bact., 85, 197.

SMith, H. W. AND Jones, J. E. T. 1963. Observations on the alimentary tract and its bacterial flora in healthy and diseased pigs. J. Path. Bact., 86, 387.

SMith, H. W. AND LINGGOOD, M. A. 1971. Observations on the pathogenic properties of the K88, Hly and Ent plasmids of Escherichia coli with particular reference to porcine diarrhoea. J. med. Microbiol., 4, 467. 
SojKa, W. J. 1965. Escherichia coli in domestic animals and poultry. Review series No. 7 of the Commonwealth Bureau of Animal Health, Weybridge.

SojкA, W. J. 1973. Enteropathogenic Escherichia coli in man and farm animals. Can. Inst. Food Sci. Technol. J., 6, 52.

SWORD, C. P. 1966. Mechanisms of pathogenesis in Listeria monocytogenes infections. I. Influence of iron. J. Bact., 92, 536.

Williams, P. H. 1979. Novel iron uptake system specified by Col V plasmids: an important component in the virulence of invasive strains of Escherichia coli. Infect. Immun. 26, 925. 